\title{
Affimers as anti-idiotypic affinity reagents for pharmacokinetic analysis of biotherapeutics
}

\author{
Hope Adamson' , Amanda Nicholl², Christian Tiede' , Anna A Tang ${ }^{1}$, Alex Davidson², Helen Curd² , Alex Wignall², Robert Ford², James Nuttall²
} Michael J McPherson', Matt Johnson² \& Darren C Tomlinson*,1

\section{ABSTRACT}

Therapeutic antibodies are the fastest growing class of drugs in the treatment of cancer, and autoimmune and inflammatory diseases that require the concomitant development of assays to monitor therapeutic antibody levels. Here, we demonstrate that the use of Affimer nonantibody binding proteins provides an advantage over current antibody-based detection systems. For four therapeutic antibodies, we used phage display to isolate highly specific anti-idiotypic Affimer reagents, which selectively bind to the therapeutic antibody idiotype. For each antibody target the calibration curves met US Food and Drug Administration criteria and the dynamic range compared favorably with commercially available reagents. Affimer proteins therefore represent promising anti-idiotypic reagents that are simple to select and manufacture, and that offer the sensitivity, specificity and consistency required for pharmacokinetic assays.

\section{METHOD SUMMARY}

Anti-idiotypic Affimer proteins that bind therapeutic antibodies are introduced as alternative affinity reagents to traditional antibodies. A nonbridging ELISA assay for pharmacokinetic analysis of these biotherapeutics in serum is developed.

\section{LAY ABSTRACT}

The fastest growing class of drugs are derived from human proteins that are modified to target the processes that cause the disease. Owing to the presence of similarly structured proteins in the blood, it is currently extremely difficult to specifically detect the therapy over the levels of normal human proteins in patients. However, it is vitally important to be able to monitor the levels of these therapies in the blood in order to ensure patients receive appropriate dosages. This paper describes the use of artificially derived proteins, called Affimers, to detect four commonly used therapies. Overall, we demonstrate that Affimer reagents provide a valid approach for monitoring dosing of these types of drugs.

\section{KEYWORDS}

Affimer reagents $\cdot$ anti-idiotypic $\cdot$ biotherapeutics - diagnostics $\cdot$ pharmacokinetics

${ }^{1}$ School of Molecular \& Cellular Biology, Astbury Centre for Structural Molecular Biology, University of Leeds, Leeds, LS2 9JT, UK; ${ }^{2}$ Avacta Life Sciences, Ash Way, Thorp Arch Estate, Wetherby, LS23 7FA, UK; *Author for correspondence: d.c.tomlinson@leeds.ac.uk

BioTechniques 67: 261-269 (December 2019) 10.2144/btn-2019-0089
Monoclonal antibody (mAb) drugs have been a resounding clinical and commercial success, applied across a range of therapeutic areas with a particularly significant impact in the treatment of cancer, autoimmune and inflammatory diseases [1-4]. High-interaction surface area binding gives mAbs greater specificity and so lower off-target, toxic effects compared with small-molecule drugs [3]. By the end of 2017, 68 mAbs or biosimilars were in clinical use and the market exceeded US\$98 billion in sales, having grown every year since 2013 [5]. This trend looks set to continue; therapeutic antibodies are the fastest growing class of drugs and in 2017 a record number of ten were granted their first marketing approvals in the USA or EU $[1,6]$. Further acceleration in $\mathrm{mAb}$ approvals is expected, with a considerable pipeline of over 550 antibodies in clinical development and over 50 in late-stage clinical trials at the end of $2017[1,6]$.

The advance in antibody therapeutics requires a parallel development of pharmacokinetic (PK) assays that can monitor $\mathrm{mAb}$ concentration and distribution in patients to guide dosage during clinical trials and practice $[7,8]$. In PK assays, the natural antigen may not be the optimal mAb capture reagent if it is expensive, hazardous or not reliably available, or when measurements of antigen-bound drug are required $[7,9,10]$. As therapeutic antibodies are highly humanized and present among up to a million-fold excess of human IgG in serum, it is particularly challenging to generate capture reagents that avoid cross-reactivity [10-12]. Antiidiotypic reagents that bind to the unique idiotopes of the antibody variable regions are required to specifically target the therapeutic antibody in PK assays $[10,13]$. Specific anti-idiotypic reagents are also required for immunogenicity assays [7,14-16], affinity purification [17], analytical studies [18] and vaccine development [19-21].

Antibodies are important as successful anti-idiotypic reagents, but their selection and production can be complex and certain limitations exist [7,10$12,18,22,23]$. With traditional immunization methods it is hard to select for specific binding to the antibody idiotype, as binding to other regions of the humanized $\mathrm{mAb}$ target molecules results in serum cross-reactivity $[7,23,24]$. Extensive screening may be required and long development times may not match the pace of drug development $[7,12,25]$. mAb technology can, however, be used to more easily generate anti-idiotypic reagents. Antibody production is also dependent on animals or mammalian cell culture to ensure correct folding, glycosylation and cysteine oxidation $[23,26]$. This complex manufacture is expensive and some antibodies have lot-tolot reproducibility issues, meaning extensive validation is required to ensure consistency throughout the drug evaluation process [27-29]. 
Table 1. Number of clones in the primary screen.

\begin{tabular}{|l|l|l|l|l|}
\hline Target & $\begin{array}{l}\text { Clones screened by } \\
\text { iQue }\end{array}$ & Hits sequenced & Unique sequences & $\begin{array}{l}\text { Clones selected for } \\
\text { ELISA tests }\end{array}$ \\
\hline Trastuzumab & 360 & Top 96 & 21 & 21 \\
\hline Rituximab CDR mAb & 192 & 192 & 102 & 17 \\
\hline Adalimumab CDR mAb & 192 & 192 & 15 & 15 \\
\hline Ipilimumab CDR mAb & 192 & 192 & 113 & 16 \\
\hline CDR: Complementary-determining region; mAb: Monoclonal antibody. &
\end{tabular}

mAbs will not have significant lot-tolot variation but there is still a desire for complementary or alternative reagents to overcome some limitations. Alternatives include anti-idiotypic antibody fragments (antigen-binding fragments [Fabs]) [7], single-chain variable fragments $[11,30]$, camelid nanobodies [31], shark variable new antigen receptors [10] and Ilama singledomain antibodies [32], and when directed selection and recombinant production is implemented reagents can often have improved consistency and specificity.

Currently, there is a particular interest in developing antibody mimetics based on nonimmunoglobulin scaffold proteins with randomized, selectable binding regions, as they can be engineered to have desirable properties [23,33-35]. Many scaffolds exist [23]; anti-idiotypic DARPins [22] and monobodies [18] have been generated, but not validated as reagents in PK assays. A promising alternative binding protein is the Affimer reagent, which is based on a cystatin scaffold with two variable, nine amino acid loops that allow high-affinity binding to a range of target molecules $[36,37]$. Affimer reagents have been used in numerous assays from studying protein function to diagnostics [37-47] and exhibit key characteristics that make them potentially suitable as anti-idiotypic reagents [45]. They can be rapidly identified, incorporating the use of negative selection [48] to direct binding towards the idiotype and reduce crossreactivity. Additionally, the small, stable scaffold can be reproducibly produced at high yield in $E$. coli, to give a reliable, consistent supply $[36,37,48]$. Here we confirm the suitability of Affimer binders as anti-idiotypic reagents; Affimer reagents against four therapeutic antibodies have been generated, characterized and validated for use in PK assays. Lot-to-lot reproducibility is evaluated and compar- isons made with anti-idiotypic Fabs to assess the advantages of Affimer reagents in terms of specificity, detection range and flexibility of assay format.

\section{MATERIALS \& METHODS}

Target QC

The target antibodies were trastuzumab (anti-HER2; Roche, Switzerland), rituximab CDR (complementary-determining regions) mAb (anti-CD20-hlgG4-mab14; Invivogen, CA, USA), adalimumab CDR mAb (anti-TNF $\alpha$-hlgG1-mab1; Invivogen) and Ipilimumab CDR mAb (Anti-CTLA4-hlgG1mab1; Invivogen). Each target antibody concentration was checked by measuring $A_{280}$ and dividing by the extinction coefficient. A 1- $\mu \mathrm{g}$ aliquot of each was analyzed by SDS-PAGE (Bolt 4-12\% Bis-Tris; Life Technologies, CA, USA) to determine quality and purity. A $100-\mu \mathrm{g}$ aliquot of each target $\mathrm{mAb}$ was then biotinylated by incubating in a 10x excess of EZ-Link SulfoNHS-LC-Biotin (21327, 1 mg no-weigh format; Thermo Fisher Scientific, MA, USA) for $2 \mathrm{~h}$ on ice. Free biotin was removed by buffer exchange, the concentration measured and a 1- $\mu \mathrm{g}$ aliquot analyzed by SDS-PAGE (as above) to check purity. Biotinylation was then confirmed by western blot analysis; $200 \mathrm{ng}$ of biotinylated target mAb was separated by SDS-PAGE (as above) and transferred onto nitrocellulose using an iBlot system (Thermo Fisher Scientific). The membrane was then blocked using $1 \times$ TBS (50 mM Tris, $150 \mathrm{mM}$ $\mathrm{NaCl}$; both Sigma, MO, USA) + 3\% bovine serum albumin (BSA; Sigma) $\mathrm{pH} 7.4$ for $1 \mathrm{~h}$ at room temperature with gentle agitation on a roller mixer. It was then washed for $3 \times 5$ min using TBS-T ( $1 \times$ TBS $+0.05 \%$ Tween 20; Sigma) and detected using a 1:10,000 dilution of streptavidin horseradish peroxidase (HRP; Abcam, UK) in 1x TBS + 3\% BSA pH 7.4 for $1 \mathrm{~h}$ at room temper- ature. The membrane was then washed as described previously and protein detected using Amersham ECL detection reagent (GE Healthcare Life Sciences, IL, USA), analyzed by chemiluminescence using a G:Box gel doc system (Syngene, India).

Phage display

Phage display was performed as described previously [48]. Briefly, targets were submitted to three rounds of phage display, with deselection against antibodies of similar isotype used to remove crossspecific binders from the phage output. For trastuzumab, a therapeutic antibody cocktail (rituximuab, Humira, Avastin and human IgG1) was used for deselection. For rituximab, adalimumab and ipilimumab CDR mAbs, deselection was performed with anti-CTLA4 hlgG4, anti-CTLA4 hlgG1 and anti-TNFa hIgG1 antibodies, respectively.

\section{Primary screen}

Following phage display, the Affimer coding regions resulting from panning rounds 2 and 3 were subcloned into pEtLECTRA vectors: cHA-His6-Cys for trastuzumab and cHA-His6 for the other mAbs. Colonies were picked (Table 1) and Affimer proteins were expressed in 1-ml cultures and purified using Ni-NTA resin (Qiagen, Germany). A primary screen was performed using the iQue Screener (Intellicyte, NM, USA). Biotinylated targets and deselection targets were immobilized onto QSH DevScreen iQue beads following the manufacturer's instructions (Intellicyte). Affimer protein concentrations were normalized to $2.5 \mu \mathrm{g} / \mathrm{ml}$ and $10 \mu \mathrm{l}$ added to $10-\mu \mathrm{l}$ prepared beads in a 384-well plate. Alexa488-conjugated anti-HA antibody (BioLegend, CA, USA) was used to quantify Affimer reagent binding. Clones were sequenced to identify unique sequences (Table 1). 


\section{Affimer protein expression}

Medium-scale recombinant Affimer protein production (50-100 $\mathrm{ml}$ ) was performed to generate 1-2 mg of Affimer material, which was purified by Ni-NTA magnetic beads (Qiagen). $5 \mathrm{ml}$ LB (made using LB [Lennox] EZ mix powder; Sigma) containing $50 \mu \mathrm{g} / \mathrm{ml}$ kanamycin sulphate (Sigma) and 1\% (w/v) glucose (Sigma) was inoculated with a sequence-checked glycerol stock for the Affimer reagent of interest and grown for $16 \mathrm{~h}$ at $37^{\circ} \mathrm{C}, 220 \mathrm{rpm} .1 \mathrm{ml}$ of starter culture was used to inoculate $100 \mathrm{ml}$ Terrific Broth (Melford, UK) containing $50 \mu \mathrm{g} / \mathrm{ml}$ kanamycin sulphate and cultures were grown at $37^{\circ} \mathrm{C}, 220 \mathrm{rpm}$ until an $\mathrm{OD}_{600}$ of $0.6-0.8$ was reached. The temperature was then reduced to $25^{\circ} \mathrm{C}$, IPTG (Sigma) added to a final concentration of $1 \mathrm{mM}$ and cultures incubated at $25^{\circ} \mathrm{C}, 220 \mathrm{rpm}$ overnight. Cells were harvested by centrifugation (10,000×g, $10 \mathrm{~min}, 4^{\circ} \mathrm{C}$ ) and resuspended in Affimer purification lysis buffer ( $\mathrm{pH}$ 8.0) comprising $50 \mathrm{mM}$ sodium phosphate (Sigma), $500 \mathrm{mM}$ sodium chloride (VWR, PA, USA), $30 \mathrm{mM}$ imidazole (Sigma), 10\% (v/v) SoluLyse (Genlantis, SA, USA), $25 \mathrm{U} / \mathrm{ml}$ Benzonase Nuclease HC (Millipore, MA, USA) and for the trastuzumab Affimer reagent $5 \mathrm{mM}$ TCEP (Generon, UK) was also added. The resuspended cells were sonicated for $5 \mathrm{~min}$ (10 s on, $10 \mathrm{~s}$ off), then the insoluble fraction was removed by centrifugation $(10,000 \times \mathrm{g}, 30 \mathrm{~min}$, $\left.4^{\circ} \mathrm{C}\right)$ and the supernatant filtered $(0.45 \mu \mathrm{m})$ to remove any remaining insoluble material. Cleared lysates were purified with Ni-NTA magnetic beads (Qiagen) using an automated process (washed in $50 \mathrm{mM}$ imidazole, eluted in $400 \mathrm{mM}$ imidazole). Purified trastuzumab Affimer reagents were buffer exchanged into $\mathrm{pH}$ 6.5 CBS (100 mM sodium citrate tribasic dehydrate $+150 \mathrm{mM}$ sodium chloride; both Sigma) + $5 \mathrm{mM}$ TCEP $+0.02 \%$ sodium azide (Severn Biotech, UK). Other Affimer reagents were buffer exchanged into $\mathrm{pH}$ 7.4 PBS (100 mM sodium phosphate $+150 \mathrm{mM}$ sodium chloride; both Sigma) $+0.02 \%$ sodium azide. The concentration (A280/extinction coefficient) and purity ( $1 \mu \mathrm{g}$ aliquot analyzed by SDS-PAGE) of all purified Affimers was measured as described previously.

\section{ELISA validation}

Selected Affimer binders (Table 1) were tested by ELISA. Affimer proteins were passively adsorbed onto Maxisorp plates at $200 \mathrm{nM}$ overnight at $4^{\circ} \mathrm{C}$. Plates were washed with 1× PBS-T (PBS diluted from 10× PBS; Gibco + 0.05\% Tween 20; Sigma), using $3 \times 300 \mu$ l per well on a BioTek (VT, USA) 405-plate washer. Wells were then blocked with $1 \times$ casein-blocking buffer (diluted in PBS from 10x casein-blocking buffer; Sigma) for $2 \mathrm{~h}$ at room temperature with gentle agitation. Plates were washed as previously and incubated with biotinylated target (at target dependent dilution) for $1 \mathrm{~h}$ at room temperature with gentle agitation. Plates were washed again and bound target was detected using a 1:10,000 dilution of streptavidin poly-HRP (Pierce, WI, USA) for $1 \mathrm{~h}$ at room temperature with gentle agitation and visualized using tetramethylbenzidine (TMB; Surmodics, MN, USA). TMB incubation time was target dependent, usually 5-10 min, and ODs were read at $450 \mathrm{~nm}$ and $630 \mathrm{~nm}$ (reference wavelength).

Affimer binders selected from the validation ELISA were then tested in a sandwich ELISA. Affimer reagents were passively adsorbed onto Maxisorp plates at $1 \mu \mathrm{g} / \mathrm{ml}$ overnight at $4^{\circ} \mathrm{C}$. Plates were washed and blocked as described previously before incubation with titrated target (twofold dilution from $2000 \mathrm{ng} / \mathrm{ml}$ ) for $1 \mathrm{~h}$ at room temperature with gentle agitation. Plates were washed again and bound target was detected with a 1:100,000 dilution of HRP-conjugated anti-hlgG antibody (Bethyl, TX, USA) for $1 \mathrm{~h}$ at room temperature with gentle agitation and visualized using TMB (Surmodics). TMB incubation time was target dependent, usually 5-10 min, and ODs were read at $450 \mathrm{~nm}$ and $630 \mathrm{~nm}$ (reference wavelength).

\section{Assay optimization}

The sandwich ELISA protocol was used to test selected Affimer proteins for specificity, lot-to-lot variation and full curve metrics.

A modified sandwich ELISA protocol was used for Fabs (anti-Trastuzumab HCA168, anti-Rituximab HCA186 and anti-Adalimumab HCA202; BioRad, CA, USA). They were passively adsorbed onto Maxisorp plates at $5 \mu \mathrm{g} / \mathrm{ml}$ overnight at $4^{\circ} \mathrm{C}$, washed as described previously and blocked with $5 \%$ BSA in PBS-T (the manufacturer recommended blocking). Plates were washed again then the titrated target series was incubated for $1 \mathrm{~h}$ at room temperature with gentle agitation before a final wash. Bound target was detected with a 1:10,000 dilution of mouse anti-human IgG (Fc) $\mathrm{CH} 2$ domain antibody (anti-hFc; BioRad) for $1 \mathrm{~h}$ at room temperature with gentle agitation and visualized using QuantaBlu (following manufacturer's protocol; Thermo Fisher Scientific).

Flexibility of detection methods was tested using the sandwich ELISA protocol with the following minor adaptations: the two generic antibodies (anti-hlgG; Bethyl at 1:100,000 and anti-hFc; BioRad at 1:10,000) used the protocol as described except that visualization was with QuantaBlu. The anti-hlgG Affimer reagent $(0.5 \mu \mathrm{g} / \mathrm{ml})$ was pre-incubated with a $1: 15,000$ dilution of streptavidin-HRP (Abcam) in blocking buffer before addition to test plate for detection ( $1 \mathrm{~h}$ at room temperature with gentle agitation) and visualization with TMB.

\section{RESULTS \& DISCUSSION}

\section{Affimer reagent selection}

An Affımer phage display library [36] was screened against four therapeutic antibodies: trastuzumab (Herceptin) and mAbs containing the CDR corresponding to the parental therapeutics rituximab (Rituxan), adalimumab (Humira) and ipilimumab (Yervoy). Screening was performed in three successive rounds against biotinylated target mAbs. Each target underwent SDS-PAGE to assess the molecular weight and purity and biotinylation was confirmed by western blot analysis. A negative selection procedure [48] was used to direct Affimer binding towards the antibody idiotype and deselect against the antibody isotype. Small amounts of isotype-specific antibody were premixed with the phage library in the second and third panning rounds, to block cross-reactive Affımer binders and selectively isolate specific anti-idiotypic Affimer reagents. Outputs from the phage panning were subcloned, recombinantly produced and purified in a small-scale automated process. A high-throughput primary screen was performed using the bead-based iQue screener (Intellicyt), with target and deselection targets immobilized onto different beads, such that selective Affimer binders with no cross-reactivity were identified. Clones were sequenced and a subset found to be unique. Of these, the highest affinity binders identified from 


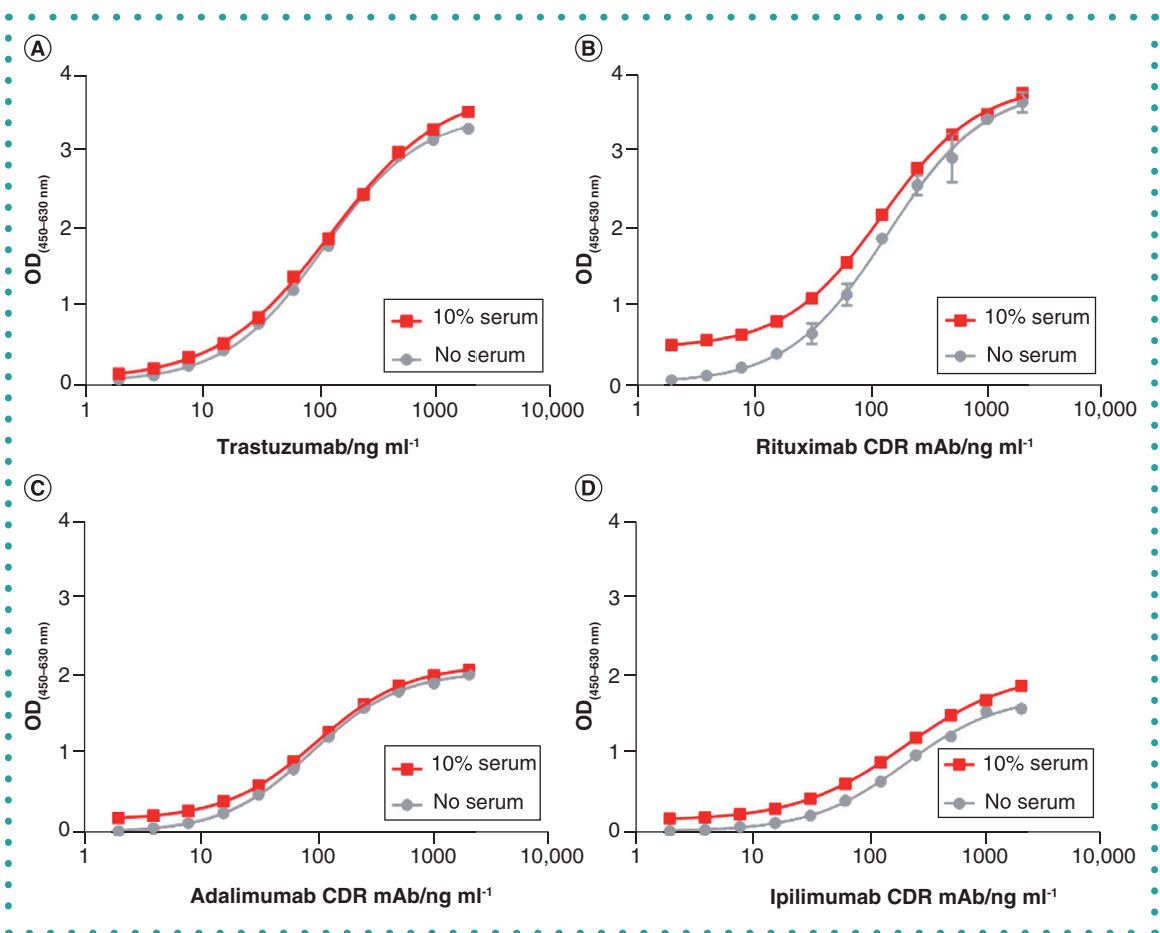

Figure 1. Sandwich ELISA dose response curves for target therapeutic antibodies with $(A)$ antitrastuzumab (B) anti-rituximab CDR mAb, (C) anti-Adalimumab CDR mAb and (D) anti-ipilimumab CDR mAb Affimer reagent capture surfaces. Detection of each target therapeutic antibody was compared in buffer (gray) and $10 \%$ human serum (red). Anti-hlgG-HGF was used as detection reagent, with TMB substrate visualization read at $450 \mathrm{~nm}$ (minus $630 \mathrm{~nm}$ reference). Data points are the mean of triplicate measurements and error bars indicate standard deviation from the mean. NB: the majority of the error bars are so small as to be occluded by the data point symbol. CDR: Complementary-determining region; mAb: Monoclonal antibody.

D iQue screening were selected for mediumscale $(50-100 \mathrm{ml})$ protein production and purification, prior to further ELISA validation. The number of clones analyzed from the primary screen is summarized for each target in Table 1.

An ELISA was used to validate the Affimer proteins as capture reagents for the biotinylated antibody targets. The bestperforming Affimer reagents were then tested in a sandwich format, using an Affimer capture surface for the nonbiotinylated $\mathrm{mAb}$ target and HRP-conjugated anti-human IgG antibody (anti-hlgG-HRP) as a detection reagent. Based upon the results of this screen, a lead candidate Affimer reagent for each target was chosen for further characterization. The lead Affimer candidate was selected to have the greatest target specificity and a binding strength optimal for the required assay range.

\section{Performance characterization} of Affimer reagents in PK assay A sandwich ELISA was developed to assess the performance of the selected anti- idiotypic Affimer reagents in quantifying therapeutic antibody concentrations. The calibration range of the assay is $1.95-2000 \mathrm{ng} / \mathrm{ml}$, corresponding to a serum concentration of $0.0195-20 \mu \mathrm{g} / \mathrm{ml}$ with samples diluted 1:10. This exemplifies the potential of Affimer binders as critical PK assay reagents, with the scope for clinically relevant serum concentrations to be measured if samples are diluted further and curves run in more diluted matrix [49-53]. The anti-idiotypic Affimer reagent was used as capture reagent for the target $m A b$, detection was with anti-hlgG-HRP and visualization with $3,3^{\prime}, 5,5^{\prime \prime}$-TMB as the HRP substrate. In this assay format each Affimer reagent detected its target $m A b$ across a broad dynamic range (Figure 1). PK assays aim to measure the target therapeutic in human serum samples, so require minimal sample matrix effects; that is, minimal variation in assay performance due to the serum matrix in which the assay is performed. A sample matrix effect was observed in the detection of the rituximab CDR mAb in 10\% human serum (Figure 1B), noted as an increase in background absorbance relative to measurements in buffer. For all other targets, minimal sample matrix effects were observed and each Affimer reagent displayed comparable detection of the target $\mathrm{mAb}$ in $10 \%$ human serum as shown in buffer (Figure 1). This confirms the success of the selection protocols in generating anti-idiotypic Affimer reagents that specifically detect clinically relevant $\mathrm{mAb}$ concentrations within a human sample matrix. The robustness of Affimer reagent performance in the presence of serum overcomes any need for advance sample preparation.

Target specificity of the anti-idiotypic reagents within patient sample matrices is crucial to ensure the efficacy of the assay, as the predominance of natural antibodies in the matrix may give rise to inaccurate measurements if any cross-reactivity exists. In the sandwich assay format, each Affimer reagent was highly specific in binding its therapeutic antibody target, showing no cross-reactivity in the presence of high concentrations $(1 \mathrm{mg} / \mathrm{ml})$ of alternative mAbs, which contain highly homologous constant domain regions to the other therapeutic antibodies and human IgGs (Figure 2). This highlights the value of the deselection protocols in driving binding towards the idiotype and demonstrates the high specificity of the isolated Affimer reagents.

\section{Affimer PK assay calibration curves} assessed against regulatory criteria The performance of the calibration curves for each anti-idiotypic Affimer sandwich assay was assessed using section III, B, 2 of the US FDA criteria for bioanalytical method validation [54]. Calibration curves were assessed in terms of the accuracy and precision of mAb quantification within a $10 \%$ human serum matrix. Triplicate measurements at each nominal concentration (1.95$2000 \mathrm{ng} / \mathrm{ml}$ as twofold dilutions) of target were performed and a four-parameter logistic regression was fitted as a calibration curve. For each measurement, an interpolated concentration was then back-calculated from this curve. Intra-assay accuracy was determined by percentage recovery; the mean interpolated concentration as a percentage of the nominal concentration. Intra-assay precision was determined by the coefficient of variation (\% CV); the standard 


\begin{tabular}{|c|c|c|c|c|c|}
\hline & & Trastuzumab & $\begin{array}{l}\text { Rituximab CDR } \\
\text { mAb }\end{array}$ & $\begin{array}{l}\text { Adalimumab CDR } \\
\text { mAb }\end{array}$ & $\begin{array}{l}\text { Ipilimumab CDR } \\
\text { mAb }\end{array}$ \\
\hline \multirow{2}{*}{$\begin{array}{l}\text { Quantifiable range } \\
(\mathrm{ng} / \mathrm{ml})\end{array}$} & ULOQ & 1000 & 1000 & 1000 & 1000 \\
\hline & LLOQ & ca. 8 & ca. 2 & ca. 4 & ca. 15 \\
\hline \multirow[t]{2}{*}{ Inter-assay } & $\% \mathrm{CV}$ & $2.3-6.2$ & $2.0-19.4^{+}$ & $1.4-7.1$ & $2.7-11.4$ \\
\hline & $\%$ recovery & $98.1-104.5$ & $95.8-104.6$ & $98.4-106.1$ & $94.4-110.9$ \\
\hline \multirow[t]{2}{*}{ Intra-assay } & $\% \mathrm{CV}$ & $2.8-24.9^{+}$ & $0.7-19.5$ & $1.2-17.3^{+}$ & $0.3-12.0$ \\
\hline & $\%$ recovery & $96.2-109.6$ & $84.0-122.3^{\dagger}$ & $95.4-112.7$ & $91.7-122.6^{+}$ \\
\hline
\end{tabular}

deviation of the interpolated concentration as a percentage of the mean. This was repeated in a total of three separate experiments and the local means used to calculate inter-assay accuracy (\% recovery) and precision (\% CV). Each of the calibration curves for the four anti-idiotypic Affimer reagents meet the following FDA performance requirements; at least $75 \%$ and a minimum of six non-zero standards (inside the anchor points) have intra-assay and interassay calibration metrics of $\leq 20 \% \mathrm{CV}$ and $80-120 \%$ recovery, with $\leq 25 \% \mathrm{CV}$ and $75-125 \%$ recovery at the lower and upper limits of quantification (LLOQ/ULOQ) (Table 2) [54]. The LLOQ and ULOQ are the lowest and highest amount of analyte that can be quantitatively determined with acceptable precision and accuracy, giving the quantifiable range for each therapeutic mAb.

The quantifiable range of ipilimumab CDR $\mathrm{mAb}$ is comparable to that of a commercially available ELISA kit (10-1000 ng/ $\mathrm{ml}$ ) [55]. The other Affimer ELISAs offer a wider quantifiable range than commercially available ELISA kits for trastuzumab $(11-300 \mathrm{ng} / \mathrm{ml})$, rituximab $(3-300 \mathrm{ng} / \mathrm{ml})$ and adalimumab (30-1000 ng/ml) [56-58]. As the anti-idiotypic Affimer-based assay calibration curves meet accuracy and precision standards over wide detection ranges, this reduces the need for dilutions and repetitions, allowing for a wider range of samples to be analyzed within a single assay. Furthermore, this is achieved with just a single specific capture reagent and universal detection format, rather than requiring two separate specific anti-idiotypic reagents, as in the case of many PK bridging
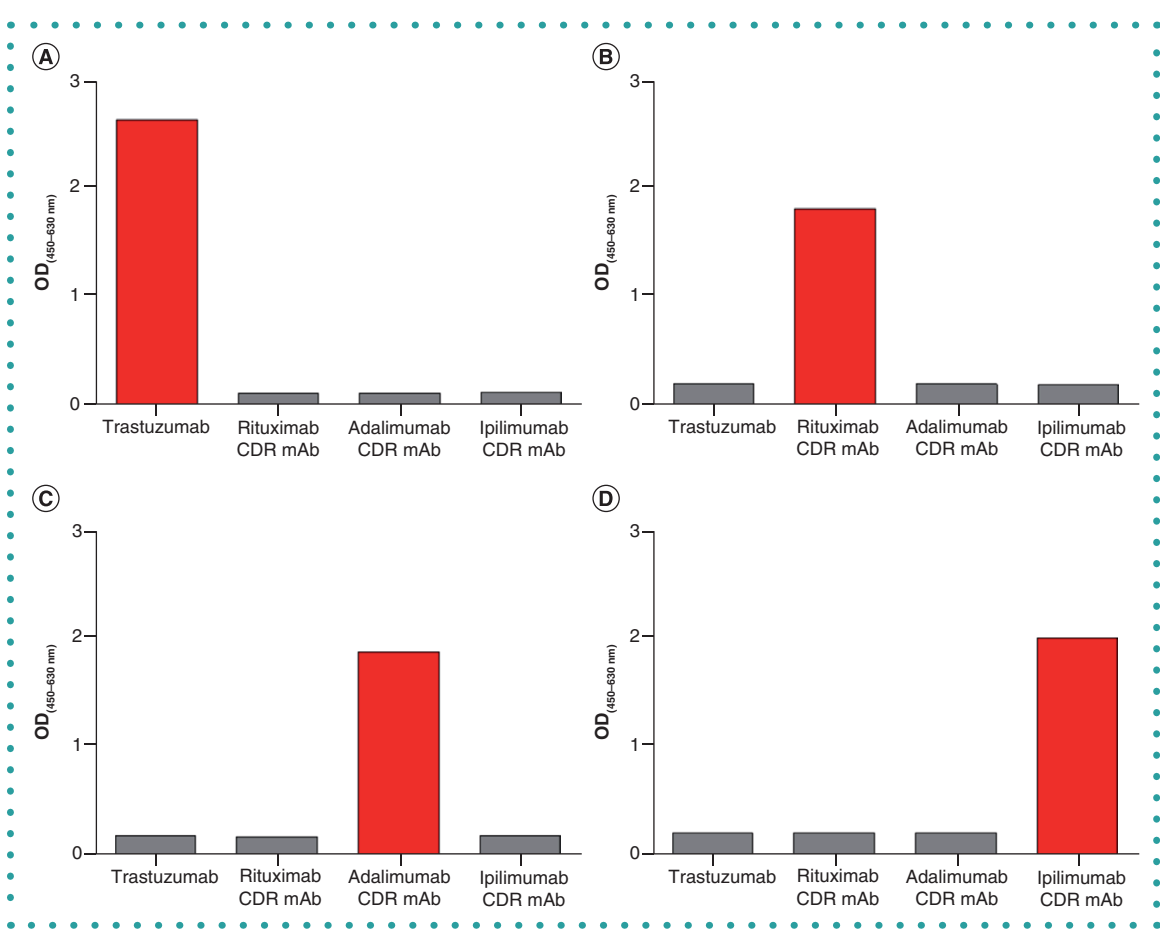

Figure 2. Specificity of therapeutic antibody detection in a sandwich ELISA using (A) anti-trastuzumab, (B) anti-rituximab CDR mAb, (C) anti-adalimumab CDR mAb and (D) anti-ipilimumab CDR $\mathrm{mAb}$ Affimer reagent capture surfaces. For each capture surface, detection of $1 \mathrm{mg} / \mathrm{ml}$ trastuzumab, rituximab CDR mAb, adalimumab CDR mAb and ipilimumab CDR mAb was compared in a $10 \%$ human serum matrix. Anti-hlgG-HRP was used as detection reagent, with TMB substrate visualization read at $450 \mathrm{~nm}$ (minus $630 \mathrm{~nm}$ reference).

CDR: Complementary-determining region; mAb: Monoclonal antibody.

assays [24]. Antibodies are not limited to the bridging format but sufficiently high-quality reagents are required.

\section{Consistent lot-to-lot reproducibility in} the performance of Affimer reagents Once validated for use in PK assays, it is important that a reliable and consistent supply of the anti-idiotypic reagent is available over the course of clinical development and usage. Anti-idiotypic antibodies can suffer from poor lot-to-lot reproducibility; therefore, extensive standardization may be required between lots to ensure assay performance is maintained $[12,25]$. This can lead to delays in the drug development process. Affimer reagents should offer low lot-to-lot variability due to their simple and robust bacterial manufacturing process. The reproducibility of the antitrastuzumab Affimer binder was assessed as an example of lot-to-lot consistency in 


\begin{tabular}{|c|c|c|c|c|c|}
\hline \multicolumn{6}{|c|}{ Trastuzumab batch comparison } \\
\hline \multicolumn{2}{|c|}{ Calibration range $(\mathrm{ng} / \mathrm{ml})$} & \multicolumn{2}{|c|}{ Inter-batch } & \multicolumn{2}{|c|}{ Intra batch } \\
\hline LLOQ & ULOQ & $\% C V$ & \%Recovery & $\%$ CV & \%Recovery \\
\hline Ca. 8 & 1000 & $0.9-13.7$ & $99.0-117.9^{+}$ & $2.2-20.0^{+}$ & $92.8-120.1$ \\
\hline
\end{tabular}

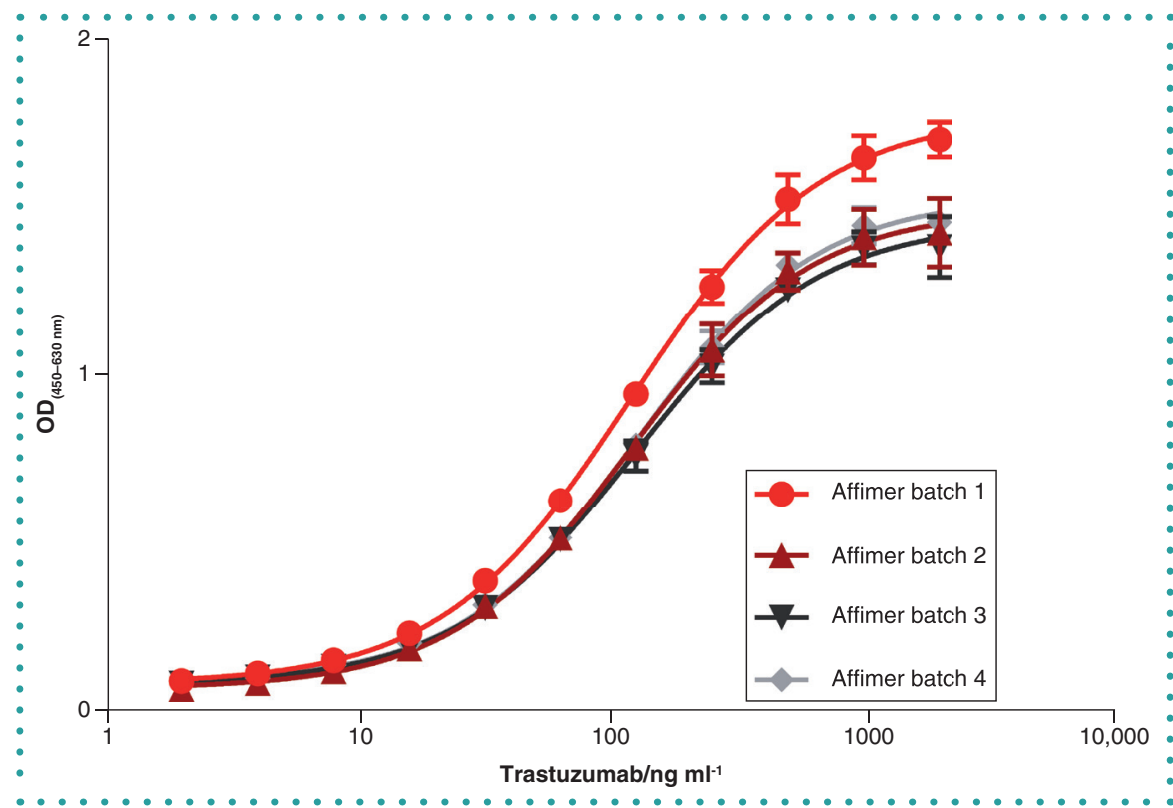

Figure 3. Lot-to-lot reproducibility of the anti-trastuzumab Affimer reagent as a capture surface in a sandwich ELISA. For four separate lots of anti-trastuzumab Affimer capture reagent the doseresponse curves of trastuzumab in a 10\% human serum matrix are compared. Anti-hlgG-HRP was used as detection reagent, with TMB substrate visualization read at $450 \mathrm{~nm}$ (minus $630 \mathrm{~nm}$ reference). Data points are the mean of triplicate measurements and error bars indicate standard deviation from the mean.

$\checkmark$ these reagents. Four separate lots were manufactured and compared by analyzing the consistency of the sandwich ELISA calibration curves (Figure 3 ) in terms of accuracy and precision.

With each Affimer lot, triplicate measurements of $1.95-2000 \mathrm{ng} / \mathrm{ml}$ trastuzumab (twofold dilution series) were made in $10 \%$ human serum (Figure 3 ) and concentrations then back-calculated from the calibration curve. Although the curve for lot 1 was slightly higher than the other three assessed, the interpolated values of each curve (intra-curve), as well as the mean of all four curves (inter-curve), met the criteria for accuracy and precision, within the previously validated quantifiable range (7.8-1000 ng/ml) (Table 3). This confirms lot-to-lot consistency in assay performance and demonstrates the high reproducibility of and $96 \mathrm{nM}$, respectively). An Fc specific detection reagent, $\mathrm{HRP}$-conjugated antihuman IgG $(\mathrm{Fc}) \mathrm{CH}_{2}$ domain antibody (antihFc-HRP), was used to prevent cross-reactivity with the Fab and the fluorogenic substrate QuantaBlu was used for visualization. Using this detection reagent, each Affimer capture reagent achieved a broad dynamic range for target detection with no clear sample matrix effects observed in $10 \%$ human serum (Figure $4 \mathrm{~A}$ ). The Fab capture reagents displayed reduced dynamic ranges for the detection of each target (Figure 4B). Greater sample matrix effects were observed in $10 \%$ human serum with the anti-adalimumab Fab and particularly the anti-rituximab Fab, compared with the equivalent Affimer binder (Figure 4B, ii \& iii). This reduces the dynamic range of the $\mathrm{Fab}$ reagents still further in this assay format and may lead to inaccurate analysis in patient samples due to serum cross-reactivity issues.

The anti-idiotypic Affimer reagents therefore exhibit increased target specificity relative to the Fabs. A single capture Affimer reagent offers such specificity that a humanized therapeutic antibody can be detected in a background of human IgGs in serum, using a universal anti-human FC (anti-hFc) detection antibody. The Fab capture surface offers insufficient specificity for the use of a universal detection format; cross-reactivity leads to the capture of serum hlgGs and their detection by anti-hFc leads to matrix effects. This issue is not inherent to antibodies, but a sufficiently high-quality reagent would need to be generated. Otherwise, in this case a bridging assay format, using the anti-idiotypic Fab as capture and detection reagent, would be necessary to enhance specificity. However, bridging assays often require optimization of a low-capture reagent coating density, to prevent bivalent binding of the therapeutic antibody that precludes binding of the anti- 


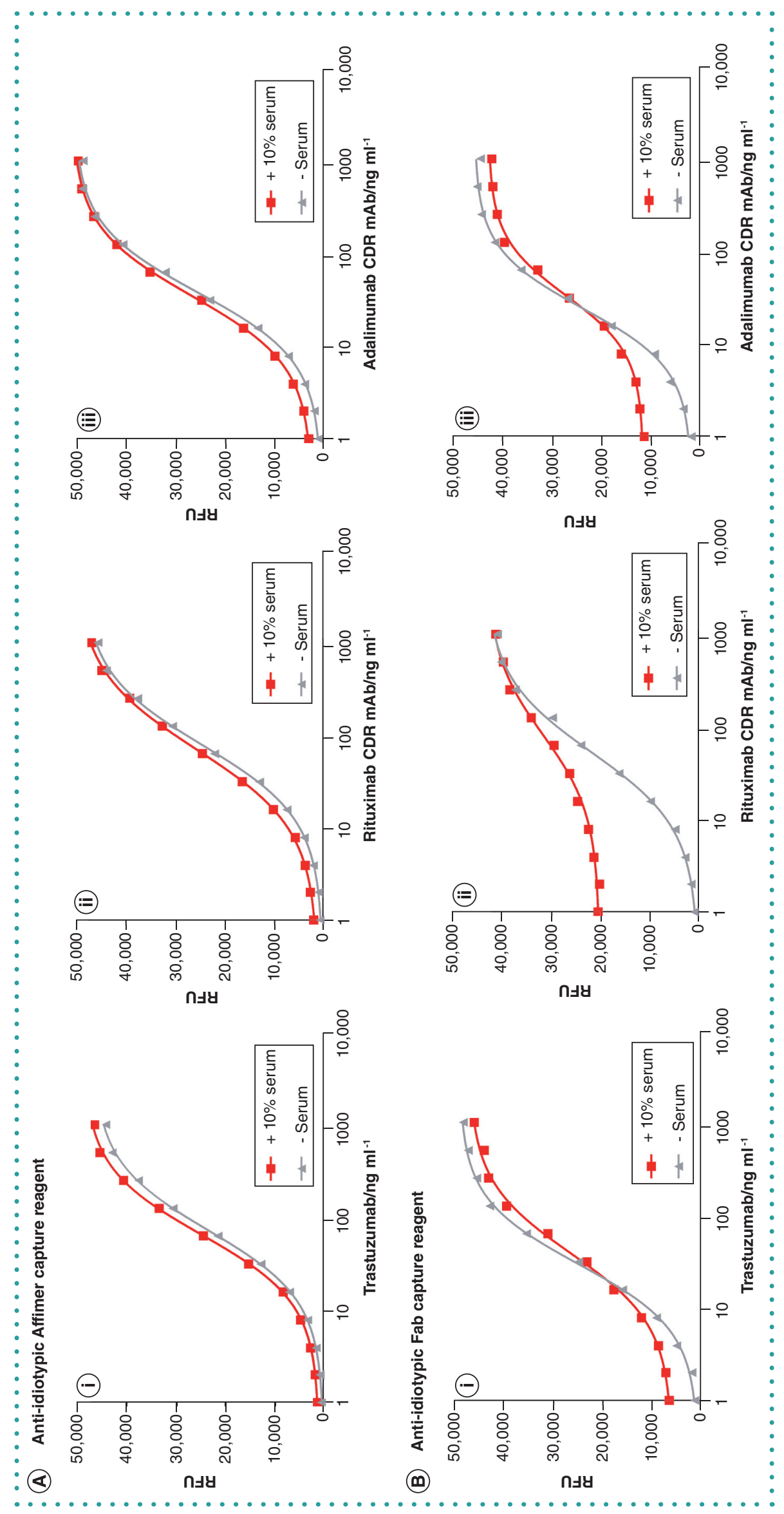

Figure 4. Comparison of (A) anti-idiotypic Affimer reagents and (B) anti-idiotypic Fabs as capture reagents for (i) trastuzumab (ii) rituximab CDR mAbs and (iii) adalimumab CDR mAbs in a sandwich ELISA. Each antiidiotypic Affimer capture reagent was coated at $1 \mu \mathrm{g} / \mathrm{ml}(70 \mathrm{nM})$ and each anti-idiotypic Fab coated at $5 \mu \mathrm{g} / \mathrm{ml}(96 \mathrm{~nm})$. Dose-response curves were obtained for the target therapeutic antibody in buffer (gray) and a $10 \%$ human serum matrix (red). Anti-hFc-HRP was used as detection reagent, with fluorogenic QuantaBlu substrate visualization. CDR: Complementary-determining region; Fab: Antigen-binding fragment; $\mathrm{mAb}$ : Monoclonal antibody.

idiotypic detection reagent [12]. The use of such low-capture reagent concentrations leads to low sensitivities and high susceptibility to inconsistencies [12]. To avoid this, two different anti-idiotypic reagents with non-overlapping binding sites would need to be found, which is very unlikely due to steric issues. Hence, the universal detection format afforded by the antiidiotypic Affimer capture approach is extremely desirable and less optimization should be required from assay to assay. Furthermore, the enhanced dynamic range offered by the Affimer reagents reduces the need for multiple dilutions and minimizes repetition of measurements.

\section{Universal Affimer detection reagent}

Both anti-hlgG-HRP and anti-hFc-HRP antibodies have been successfully used as detection reagents, alongside anti-idiotypic Affimer capture reagents. Further flexibility in detection format was demonstrated by the use of a universal anti-hlgG Affimer detection reagent (Figure 5), giving an Affimer-only assay format. The anti-hlgG Affimer was biotinylated and pre-incubated with streptavidin-HRP prior to detection and visualization with TMB.

For detection of both trastuzumab and rituximab CDR mAbs, minimal matrix effects were observed in $10 \%$ serum (Figure 5) and the dynamic ranges were comparable to those obtained with anti-hlgG antibodies. The intra-assay curve metrics for trastuzumab in $10 \%$ serum gave a quantifiable range of $2-2000 \mathrm{ng} / \mathrm{ml}$, with $\leq 18.0 \%$ CV and $93.9-115 \%$ recovery. In $10 \%$ serum rituximab CDR mAb had a quantifiable range of $7.8-2000 \mathrm{ng} / \mathrm{ml}$, with $\leq 17.7 \%$ CV and $95.3-110.7 \%$ recovery. This again 


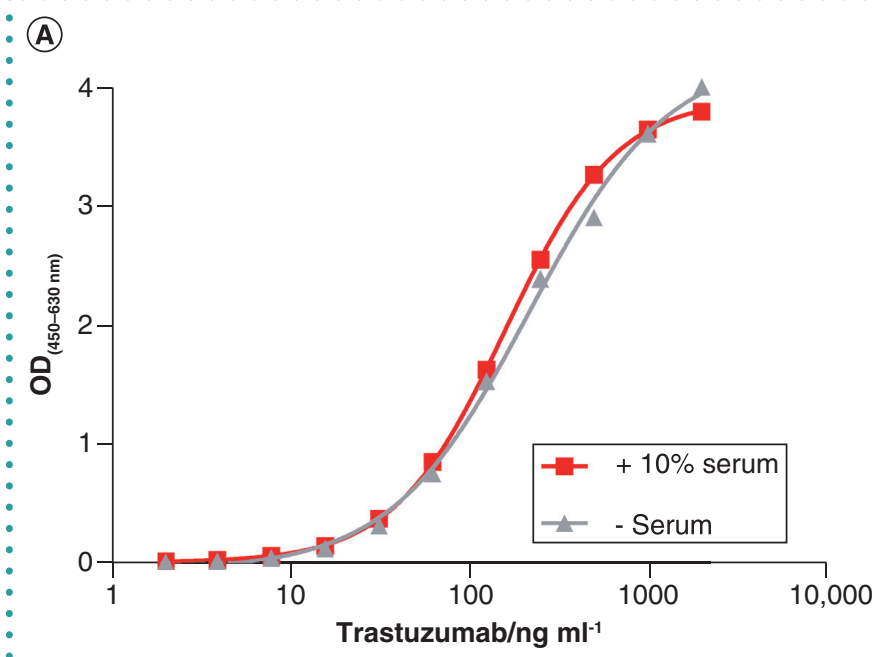

(B)

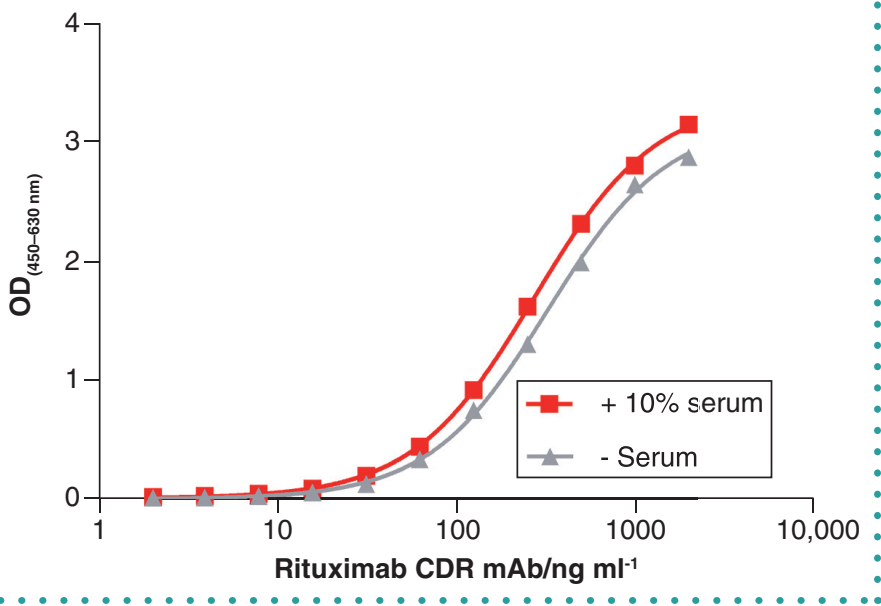

Figure 5. Sandwich ELISA dose response curves using anti-hlgG Affimer as detection reagent with (A) anti-trastuzumab and (B) anti-rituximab CDR mAb Affimer reagent capture surfaces. Therapeutic antibodies were detected in buffer (gray) and a $10 \%$ serum matrix (red). Visualization was with TMB substrate read at $450 \mathrm{~nm}$ (minus $630 \mathrm{~nm}$ reference).

D demonstrates the excellent specificity of the Affimer capture surfaces, allowing a number of different universal detection formats to be successfully employed, which offers assay developers flexibility to suit individual assay requirements. The Affimer sandwich assay format obviates the need for antibodies and each binding reagent is an easily manufactured recombinant protein. Furthermore, the detection reagent is universal, so should be applicable across assays, simplifying assay development and reagent manufacture.

The generation of anti-idiotypic affinity reagents against therapeutic mAbs presents a particular challenge. In order to specifically recognize a humanized therapeutic antibody within the high background of human IgGs present in serum, reagents must be highly specific for the mAb idiotype. Here we demonstrate Affimer reagents to be easily selected and manufactured non-immunoglobulin reagents that can address this challenge. Anti-idiotypic Affimer reagents against trastuzumab and CDR mAbs of rituximab, adalimumab and ipilimumab therapeutic antibodies have been identified and characterized. A simple negative selection protocol successfully drove binding towards the target idiotype, generating highly specific Affimer binders that display minimal matrix effects in $10 \%$ human serum and no cross-reactivity with nonspecific mAbs, without any need for affinity maturation. Compared with equiv- alent Fabs, the anti-idiotypic Affimer capture surfaces offered such exquisite specificity that a flexible universal detection format (anti-hlgG antibody, anti-hFc antibody or anti-hlgG Affimer) can be used, avoiding bridging assays and simplifying assay development. A sandwich ELISA using antiidiotypic Affimer capture and universal antihlgG-HRP antibody detection was developed within a $10 \%$ human serum matrix. Calibration curves met the FDA criteria for accuracy and precision over favorable dynamic ranges in comparison to Fabs and commercially available kits, confirming the applicability of anti-idiotypic Affimers to PK assays. The lot-to-lot consistency of the antitrastuzumab Affimer was also confirmed, giving assurance of supply.

Overall, it is clear that the Affimer platform can be reliably used to develop anti-idiotypic reagents for immunoassays, to measure relevant concentrations of therapeutic mAbs with suitable accuracy and precision metrics for calibration curves. As well as being simple to identify and easy to produce, the anti-idiotypic Affimer reagents offer performance improvements in terms of high specificity, low matrix effects, broad dynamic ranges, flexible universal detection formats and low lot-to-lot variation. The fast reagent development time, ease of assay development and assurance of supply make the highly specific anti-idiotypic Affimers promising reagents to meet the demands of clinical development timelines and prevent delays, particularly in the growing biosimilars arena, where speed to market is essential. The development of antibody therapeutics continues to expand and antiidiotypic Affimer reagents offer the potential for critical partner PK assays.

\section{FUTURE PERSPECTIVE}

Increasing numbers of biologics entering drug development and achieving regulatory approval, combined with the rising rates of patients suffering with chronic diseases, ensures that critical reagents for pharmacokinetic studies will remain an essential building block within the drug development pipeline. Current pharmacokinetic assay reagents can be costly to produce and require long development times, which hinder the drug development process. As the technology driving non-immunoglobulin alternatives to antibodies expands, bioanalysts will continue to explore both antibody and non-antibody-based critical reagents when establishing PK and therapeutic drug monitoring assays. Reagent selection will depend upon superior performance, delivery speed and simple and cost-effective assay design and development. We foresee that these critical reagents may also have application in both drug monitoring and patient selection in the future.

\section{AUTHOR CONTRIBUTIONS}

HA, CT and AAT performed phage display and isolation of Affimer reagents. $A N, A D$, 
$H D, A W, R F$ and JN performed the ELISAs and validation experiments. HA, MJM, MJ and DCT conceived the idea, supervised the experiments and wrote the paper. All the authors read and edited the manuscript.

\section{FINANCIAL \& COMPETING INTERESTS DISCLOSURE}

MJM and DCT: Inventors of the Adhiron/ Affimer technology and own personal shares in Avacta Life Sciences. The Adhiron patent (patent application number PCT/ GB2014/050435) is owned by the University of Leeds and licensed to Avacta Ltd. AM, AD, $\mathrm{HC}, \mathrm{AW}, \mathrm{RF}, \mathrm{JN}$ and MJ all work for Avacta Life Sciences. The authors have no other relevant affiliations or financial involvement with any organization or entity with a financial interest in or financial conflict with the subject matter or materials discussed in the manuscript apart from those disclosed.

No writing assistance was utilized in the production of this manuscript.

\section{OPEN ACCESS}

This work is licensed under the AttributionNonCommercial-NoDerivatives 4.0 Unported License. To view a copy of this license, visit http://creativecommons.org/licenses/ by-nc-nd/4.0/

\section{REFERENCES}

Papers of special note have been highlighted as: • of interest

1. Carter PJ, Lazar GA. Next generation antibody drugs: pursuit of the 'high-hanging fruit'. Nat. Rev. Drug Discovery. 17(3), 197-223 (2018)

2. Leavy $O$. Therapeutic antibodies: past, present and future. Nat. Rev. Immunol. 10(5), 297 (2010).

3. Shepard HM, Phillips GL, Thanos CD, Feldmann M. Developments in therapy with monoclonal antibodies and related proteins. Clin. Med. 17(3), 220-232 (2017).

4. Elgundi Z, Reslan M, Cruz E, Sifniotis V, Kayser V. The state-of-play and future of antibody therapeutics. Adv. Drug Delivery Rev. 122, 2-19 (2016).

5. Grilo AL, Mantalaris A. The increasingly human and profitable monoclonal antibody market. Trends Biotechnol. 37(1), 9-16 (2018).

6. Kaplon H, Reichert JM. Antibodies to watch in 2018. $m A b s$ 10(2), 183-203 (2018).

7. Chin SE, Ferraro F, Groves M, Liang M, Vaughan TJ, Dobson CL. Isolation of high-affinity, neutralizing anti-idiotype antibodies by phage and ribosome display for application in immunogenicity and pharmacokinetic analyses. J. Immunol. Methods. 416, 49-58 (2015).

8. Keizer RJ, Huitema AD, Schellens JH, Beijnen JH. Clinical pharmacokinetics of therapeutic monoclonal antibodies. Clin. Pharmacokinet. 49(8), 493-507 (2010).

9. Lim SY, Chan CE, Lisowska MM, Hanson BJ, MacAry PA. The molecular engineering of an anti-idiotypic antibody for pharmacokinetic analysis of a fully human anti-infective. PloS One 10(12), e0145381 (2015)

10. Könning D, Rhiel L, Empting $M$ et al. Semi-synthetic vNAR libraries screened against therapeutic antibodies primarily deliver anti-idiotypic binders. Sci. Rep. 7(1)
9676 (2017) 9676 (2017)

- Describes anti-idiotypic vNAR reagents.
11. Tornetta M, Fisher D, O'Neil K et al. Isolation of human anti-idiotypic antibodies by phage display for clinical immune response assays. J. Immunol. Methods. 328(1-2), 34-44 (2007).

12. Salimi-Moosavi $\mathrm{H}$, Winters $\mathrm{A}$, Abbott $\mathrm{C}$ et al. A multifactorial screening strategy to identify anti-idiotypic reagents for bioanalytical support of antibody therapeutics. Anal. Biochem. 470, 52-60 (2015).

13. Ameri M, Zhou E-M. Idiotypes and anti-idiotypic antibodies: a review. Comp. Clin. Pathol. 14(4), 171-178 (2006)

14. van Schie KA, Wolbink G-J, Rispens T. Cross-reactive and pre-existing antibodies to therapeutic antibodies effects on treatment and immunogenicity. mAbs. 7(4), 662-671 (2015)

15. Warnke C, Hermanrud C, Lundkvist M, Fogdell-Hahn A Anti-drug antibodies. Drugs Ther. Stud. 2(1), e11 (2012).

16. Krishna M, Nadler SG. Immunogenicity to biotherapeutics-the role of anti-drug immune complexes. Front. Immunol. 7, 21 (2016).

17. Godar M, Morello V, Sadi A et al. Dual anti-idiotypic purification of a novel, native-format biparatopic anti-MET antibody with improved in vitro and in vivo efficacy. Sci. Rep. 6, 31621 (2016).

18. Sullivan MA, Brooks LR, Weidenborner $P$ et al. Anti-idiotypic monobodies derived from a fibronectin scaffold. Biochemistry. 52(10), 1802-1813 (2013).

- Describes anti-idiotypic monobody reagents.

19. Ladjemi MZ. Anti-idiotypic antibodies as cancer vaccines: achievements and future improvements. Front Oncol. 2, 158 (2012).

20. Mader A, Kunert R. Humanization strategies for an anti-idiotypic antibody mimicking HIV-1 gp41. Protein Eng. Des. Sel. 23(12), 947-954 (2010)

21. Vázquez AM, Hernández AM, Macías A et al. Racotumo mab: an anti-idiotype vaccine related to $\mathrm{N}$-glycolyl-containing gangliosides-preclinical and clinical data. Fron Oncol. 2, 150 (2012).

22. Vogel M, Keller-Gautschi E, Baumann MJ et al. Designed ankyrin repeat proteins as anti-idiotypic-binding moleankyrin repeat proteins as anti-idiotypic-binding
cules. Ann. NY Acad. Sci. 1109(1), 9-18 (2007).

23. Yu X, Yang YP, Dikici E, Deo SK, Daunert S. Beyond antibodies as binding partners: the role of antibody mimetics in bioanalysis. Annu. Rev. Anal. Chem. 10, 293-320 (2017).

24. Lee JW, Kelley M, King LE et al. Bioanalytical approaches to quantify "total" and "free" therapeutic antibodies
and their targets: technical challenges and PK/PD applications over the course of drug development. AAPS J. 13(1), 99-110 (2011).

25. Wang X, Quarmby V, $\mathrm{Ng} \mathrm{C}$ et al. Generation and characterization of a unique reagent that recognizes a panel of recombinant human monoclonal antibody therapeutics in the presence of endogenous human IgG. mAbs. 5(4), 540-554 (2013).

26. Vazquez-Lombardi R, Phan TG, Zimmermann C, Lowe D, Jermutus $L$, Christ $D$. Challenges and opportunities for non-antibody scaffold drugs. Drug Discov. Today. 20(10) 1271-1283 (2015).

27. Chames $P$, Van Regenmortel M, Weiss E, Baty D. Therapeutic antibodies: successes, limitations and hopes fo the future. Br. J. Pharmacol. 157(2), 220-233 (2009).

28. Bradbury A, Pluckthun A. Standardize antibodies used in research: to save millions of dollars and dramatically improve reproducibility, protein-binding reagents must be defined by their sequences and produced as recombinant proteins, say Andrew Bradbury, Andreas Pluckthun and 110 co-signatories. Nature 518(7537), 27-30 (2015).

29. Bordeaux J, Welsh AW, Agarwal S et al. Antibody validation. BioTechniques 48(3), 197-209 (2010).

30. Coelho M, Gauthier P, Pugniere M, Roquet F, Pelegrin A, Navarro-Teulon I. Isolation and characterisation of a
human anti-idiotypic scFv used as a surrogate tumour human anti-idiotypic scFv used as a surrogate tumour mice. Br. J. Cancer 90(10), 2032-2041 (2004).

31. Wang $Y, L i$ P, Majkova $Z$ et al. Isolation of alpaca anti-idiotypic heavy-chain single-domain antibody for the aflatoxin immunoassay. Anal. Chem. 85(17), 8298-8303 (2013).

32. Alvarez-Rueda N, Ladjemi MZ, Béhar G et al. A llama single domain anti-idiotypic antibody mimicking HER2 as a vaccine: Immunogenicity and efficacy. Vaccine $27(35)$, 4826-4833 (2009)

33. Škrlec K, Štrukelj B, Berlec A. Non-immunoglobulin scaffolds: a focus on their targets. Trends Biotechnol. 33(7) 408-418 (2015)

34. Jost C, Plückthun A. Engineered proteins with desired specificity. DARPins, other alternative scaffolds and bispecific IgGs. Curr. Opin. Struct. Biol. 27, 102-112 (2014). 35. Gilbreth RN, Koide $\mathrm{S}$. Structural insights for engineering
binding proteins based on non-antibody scaffolds. Curr. Opin. Struct. Biol. 22(4), 413-420 (2012).
36. Tiede C, Tang AA, Deacon SE et al. Adhiron: a stable and versatile peptide display scaffold for molecular recognition applications. Protein Eng. Des. Sel. 27(5) 145-155 (2014).

37. Tiede C, Bedford R, Heseltine SJ et al. Affimer proteins are versatile and renewable affinity reagents. eLife 6 , e24903 (2017)

38. Schlichthaerle T, Eklund A, Schueder F et al. Site-specific labeling of Affimers for DNA-PAINT microscopy. Angew. Chem. Int. Ed. 57(34), 11060-11063 (2018).

39. Lopata A, Hughes R, Tiede $\mathrm{C}$ et al. Affimer proteins for F-actin: novel affinity reagents that label F-actin in live and fixed cells. Sci. Rep. 8(1), 6572 (2018).

40. Zhurauski P, Arya SK, Jolly P et al. Sensitive and selective Affimer-functionalised interdigitated electrode-based capacitive biosensor for Her4 protein tumour biomarker detection. Biosens. Bioelectron. 108, 1-8 (2018).

41. Robinson JI, Baxter EW, Owen RL et al. Affimer proteins inhibit immune complex binding to Fc $\gamma$ RIIla with high specificity through competitive and allosteric modes of action. Proc. Natl Acad. Sci. USA 115(1), E72-E81 (2018).

42. Hughes DJ, Tiede C, Penswick $\mathrm{N}$ et al. Generation of specific inhibitors of SUMO-1-and SUMO-2/3-mediated protein-protein interactions using Affimer (Adhiron) technology. Sci. Signal. 10(505), eaaj2005 (2017).

43. Xie C, Tiede $C$, Zhang $X$ et al. Development of an Affim er-antibody combined immunological diagnosis kit for

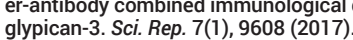

44. Arrata I, Barnard A, Tomlinson DC, Wilson AJ. Interfacing native and non-native peptides: using Affimers to recognise $\alpha$-helix mimicking foldamers. Chem. Commun. 53(19), 2834-2837 (2017).

45. Sharma R, Deacon SE, Nowak D et al. Label-free electrochemical impedance biosensor to detect human interleukin-8 in serum with sub-pg/ml sensitivity. Bios ens. Bioelectron. 80, 607-613 (2016).

46. Rawlings $A E$, Bramble JP, Tang $A A$ et al. Phage display selected magnetite interacting Adhirons for shape controlled nanoparticle synthesis. Chem. Sci. 6(10), 5586-5594 (2015)

47. Kyle HF, Wickson KF, Stott J et al. Exploration of the HIF- $1 \alpha /$ p300 interface using peptide and Adhiron phage display technologies. Mol. BioSyst. 11(10), 2738-2749 (2015).

48. Ah-San Tang A, Tiede C, Hughes DJ, McPherson MJ, Tomlinson DC. Isolation of isoform-specific binding proteins (Affimers) by phage display using negative selection. Sci. Signal. 10(505), eaan0868 (2017).

49. Hampson G, Ward TH, Cummings $\mathrm{J}$ et al. Validation of an ELISA for the determination of rituximab pharmacokinetics in clinical trials subjects. J. Immunol. Methods 360(1-2), 30-38 (2010)

50. Desvignes C, Edupuganti SR, Darrouzain F et al. Development and validation of an enzyme-linked immunosorbent assay to measure adalimumab concentration. Bioanalysis 7(10), 1253-1260 (2015).

51. Weber JS, O'Day S, Urba W et al. Phase I/II study of pilimumab for patients with metastatic melanoma. $J$. Clin. Oncol. 26(36), 5950-5956 (2008).

52. Cardinali B, Lunardi G, Millo E et al. Trastuzumab quantification in serum: a new, rapid, robust ELISA assay based on a mimetic peptide that specifically recognizes trastuzumab. Anal. Bioanal. Chem. 406(18), 4557-4561 (2014).

53. Damen CW, de Groot ER, Heij M et al. Development and validation of an enzyme-linked immunosorbent assay for the quantification of trastuzumab in human serum and plasma. Anal. Biochem. 391(2), 114-120 (2009).

54. Guidance for industry: Bioanalytical method validation. US Department of Heath and Human Services Food and Drug Administration (2018)

55. abcam. Ipilimumab ELISA Kit (Yervoy ${ }^{\circledR}$ ). https://www. abcam.com/ipilimumab-elisa-kit-yervoyreg-ab237653. html

56. abcam. Trastuzumab ELISA Kit (Herceptin ${ }^{\circledR}$ ) https:// www.abcam.com/trastuzumab-elisa-kit-herceptinreg-ab237645.html

57. abcam. Rituximab ELISA Kit (Mabthera $\left.{ }^{\circledR}\right)$. https://www. abcam.com/rituximab-elisa-kit-mabtherareg-ab237640. html

58. abcam. Adalimumab ELISA Kit (Humira ${ }^{\circledR}$ ). https://www. abcam.com/adalimumab-elisa-kit-humirareg-ab237641. html

59. Ylera F, Harth S, Waldherr D, Frisch C, Knappik A. Offrate screening for selection of high-affinity anti-drug antibodies. Anal. Biochem. 441(2), 208-213 (2013). 